\title{
restorative programs in the formal justice system of vanuatu
}

\begin{abstract}
Hon. Justice Vincent Lunabek
Chief Justice of the Supreme Court of the Republic of Vanuatu, expressed his delight at being invited to participate in this conference and asked to contribute to its published proceedings. He also expressed regret that he knew very little about 'restorative justice' in the formal justice system. He nevertheless provided insights based on his involvement with alternative dispute resolution.
\end{abstract}

\section{Administrative bodies and adjudication}

Much recent activity in the field of civil justice reform has concentrated on the courts and the use of Alternative Dispute Resolution (ADR). This is a limited view of the enterprise for both practical and theoretical reasons. In simple terms of volume and seriousness, disputes that are resolved by administrative agencies are of enormous day-to-day importance to citizens. Viewed as part of the gradual devolution of judicial tasks to bodies outside the court system, administrative agencies are where ADR originated.

There is much to learn from how the matters that were diverted from the courts were identified, and from how ADR processes were selected. There is also much to learn from how a relationship developed between the courts and the alternative dispute resolution system. Moreover, like courts, but probably unlike most other ADR mechanisms, administrative agencies not only process disputes. They also create rights and entitlements. Administrative bodies are a source of considerable diversity and complexity in the available means of dispute resolution. Some examples of this type of body include: 
- $\quad$ the Office of the Ombudsman;

- the Public Service Commission;

- $\quad$ the Judicial Services Commission;

- $\quad$ the Teaching Service Commission;

- Tribunals, etc.

Many aspects of disputes arising in daily life are channelled to administrative agencies. They are part and parcel of the civil justice system. Administrative agencies were developed in response to concerns that the courts were not the most appropriate forum for dealing with certain matters, e.g. employment disputes. In short, administrative agencies were seen as a way of overcoming some of the perceived inadequacies of substantive laws and existing structures for applying them.

The evolution of administrative agencies has been marked by intense concern with procedural matters and increasing 'judicialisation'. This demonstrates that the basic elements of decision making as understood in the courts resonate far outside the courtroom.

\section{Courts and ADR}

The term 'alternative dispute resolution' or, better, 'appropriate dispute resolution' refers to a wide range of methods by which conflicts and disputes are resolved, other than through (judicial) litigation. These include a variety of formal and informal approaches directed at the prevention and/or resolution of disputes that also, in some instances, address the underlying causes of conflict.

Many forms of ADR are aimed not only at the settlement of disputes but also at providing a process that can restore the relationship between the parties in a dispute and that can reaffirm each party's dignity and autonomy. ADR is not a new concept to Pacific Island jurisdictions and, in particular, to Vanuatu. It is, in fact, consistent with traditional methods of dispute resolution that predated the introduction of the formalised system of justice.

Given the need to incorporate ADR within the formal courts system, a number of preliminary steps have to be taken. 
First, the Rules of Court need to be reviewed and revised, and case management techniques should be introduced. The rationale here is that the courts should bear responsibility for, and control of, the cases that come before them. Secondly, there is the need to incorporate some form of ADR, such as mediation, into the formal court processes. This would require the integral involvement of the courts, not only in facilitating ADR but also in actually providing ADR services such as mediation or neutral evaluators, as well as appropriate physical facilities.

ADR has an important role to play in relation to restorative justice. It has a number of advantages in this regard. It assists in the maintenance of good relationships. This is especially important in a small jurisdiction like Vanuatu where people are interrelated in many aspects of community life through blood ties and other forms of association. ADR and restorative justice are appropriate in a society that is based on consensual settlement, such as ours. The use of ADR methods can also contribute to speedier settlement of disputes. This is in contrast to formal court proceedings that usually take a long time. ADR can help make the work of the courts more effective. It can be used in a wide variety of legal areas, including labour law, family law, environmental law, commercial law, land law and public law.

\section{Use of ADR in the criminal justice system}

In Vanuatu, there are constitutional and legislative provisions that allow the courts to consider custom and customary law. In respect to mitigation and the sentencing process, the courts can look to ss118 \& 119 of the Criminal Procedure Code (Cap 136). However, there remain some ambiguities arising from the consideration of custom in the sentencing process. Legislative intervention is necessary for the purpose of clarification.

\section{Use of ADR as an alternative to trial in cases involving juveniles}

The relevant legislative provisions relating to this issue are ss38, 42 and 43 of the Vanuatu Penal Code (Cap 135). Here are some suggestions for consideration: 


\section{Consent order}

This would apply to a first time (juvenile) offender charged with a minor offence. Under a consent order, the juvenile would be placed on voluntary probation without any admission or mention of guilt. If $\mathrm{s} /$ he avoids trouble during the period of probation, then the charge would be dismissed. If s/he gets into more trouble during this period, the charge would be reinstated and the young person made to stand trial.

Diversion program

In a program such as this, the young offender does not go to trial. Instead, s/he returns the property or pays for property destroyed or, alternatively, participates in some kind of voluntary work or whatever else the judge or magistrate determines as appropriate reparation for the wrongdoing.

In addition, juveniles can plead guilty in order to avoid going to trial.

There is also scope for the use of ADR techniques as part of rehabilitation programs both inside and outside prisons.

\section{Conclusion}

The introduction of restorative programs into the formal justice system presents challenges for national leaders, law enforcement agencies, community leaders and the public at large. It brings with it the need to change attitudes and develop understanding and co-operation. This is a necessary part of achieving the required legislative changes, their acceptance and their funding. 